The earlier part of the second memoir ( 28 pp.) treats of points, lines, and polygons, and swarms with results, upon the novelty or antiquity of which we cannot pronounce a judgment. We have then some proofs given of properties of the Tricusp, which is the envelope of the feet perpendicular lines of an inscribed triangle. Steiner's enunciations ("Creile," vol. 53) have been demonstrated by Prof. Townsend ("Reprint from Educational Times," vol. iv. pp. 13-17), Prof. Cremona ("Crelie," vol. 64), and by other mathematicians.* An appendix of eleven pages, entitled "Ueber Raumcurven vierter Ordnung erster Art, und eine spezielle ebene curve vierter Ordnung $\mathrm{C}_{1}^{4}$ " closes the memoir.

The last memoir on our list ( $39 \mathrm{pp}$.) is a very interesting one, in which a great number of properties of the curve are established by means of its ordinary rectangular cquation $\left(x^{2}+y^{2}\right)^{2}-2 a^{2}\left(x^{2}-y^{2}\right)=0$. We should like to see this memoir in an English clress. On the authority of a German friend, we may say that it is written in elegant German, All three memoirs are extracted from the "Abhandlungen der k. böhm. Gesellsch. der Wissenschaften" (vi. folse, 6 Band). Whether the practice obtains on the Continent to any extent of thus reprinting separate memoirs we cannot say, but we learn from a distincuished physicist that such is the case with the Vierna "Transactions," of which any paper may be had separately through a bookseller at a price published in the table of contents. This is a laidable practice, and in these columns the desirableness of its introduction into this country has been more than once dwelt upon. Hapoily, we learn from the President's address (NATURE, vol, xi. p. I97) that the Royal Society have the matter under consideration. As the reasons pro and con have so recently been given, it would be out of place here to dwell longer on the matter. We hope, however, that it will be possible on some terms or other to get separate memoirs in the case of those societies whose publications embrace tivo or more specialities. A practice obtains in some societics of allowino reader; of papers to have extra copies of their own papers, at reasonable prices, for distribution. Possibly, the best mode of proceeding at present for a specialist who wants a particular paper is for him to apply to the author on the chance of his having these extra copies.

Botanischer fahresbericht: Systematisch geordenetes Repertorimn der Botanuschen Literatum aller Länder. Herausgegeben von Dr. Leopold Just. (Berlin: Gebrider Bertraeger, 1873.)

WrTH the rapid increase of botanical literature of every kind during the last few years every working botanist must have proved the inconvenience of having no work of reference at hand like this "Botanischer Jahresbuch," and particularly those who are engaged in any special inquiry involving much research and an extensive knowlcdge of the literature of his subject. As the preface to this excellent részmene of the botanical literature of 1873 truly says, "Alnıst every botanist has passed through the experience of having read through bulky treatises with the expenditure of much time, only to complain that it is so much time lost. On the other hand, it happens freguently enough that very important treatises appear in periodicals where they are not exactly looked for by botanists, and consequently frequently remain unknown and unused for years." "This need no longer be the case, if the success which this undertaking thoroughly deserves is granted it, and warrants the continuance of it from year to year.

The work has been published in two half-volumes, and the first part or half-volume summarises the investigations which have been made, and the literature published on the various groups of the Cryptogamia, together with divisions on the morphology of cells, the morphology of tissues, the special morphology of conifers, the morpho-

* There is an article "Sur l'Hypocycloïde à trois Rebroussements" in the "Nouvelles Annales" (pp. 2x-3r), Janvier, 1875. logy of the Phanerogamia (monocotyledons and dicotyledons), and Physical and Chemical Physiology, continued in the second half-volume, which further contains divisions on fructification and reproduction, hybridation, origin of species. Lists and notices of systematic morographs and extra-European floras stand next in order, together with Palreobotany, treated according to the succession of formations, beginning with the Primary or Palaozoic formation. The other portions embrace pharmaceutical botany, technical botany, botany applied to forest management, diseases of plants, and geographical distribution.

The aim of the editors has been to give as complete a view as possible of the literature of the several subjects above mentioned, and with regard to most of the departments this has been successfully accomplished, but omissions occur in some of the divisions, particularly in those on the cellular cryptogams and the morphology of tissues. No notice, $c . o^{\text {., }}$ is taken of the important work of Strasburger on Azolla and the Lycopodiacex, nor the work of Juranyi on the spores of Salvinita natins. Some of the omissions Dr. Just promises to rectify in the next year's volume.

In this deficient section, however, it may be observed that ail newly constituted species amongst the Diatomacea and fungi are carefully noted, and of the latter brief descriptions are given. As an appendix to the fungi appears a section on the nutrition of the lower oranisms.

T'le above-mentioned divisions of the work embrace all that has been published in the time specitied ( 1873 ) in the German, French, and English languages. The literature of other countries is treated in special sections, each under the care of an editor chosen for the purpose; viz., Dutch, Italian, Russiain, and Hungarian botanical literiture. Dr. Just laments that it has not been possible to include the literature of Denmark, Norway, and Sweden in this first volume. This, however, will not be omitted in future volumes, a suitable editor having been chosen for the purpose.

\section{LETTEES TO THE EDITOR}

[The Editor does not hold himself responsible for opintons expressed by his correspondents. Neither can he undertake to return, or to correspond with the wrilers of, rejected manuscripts. No notace is taken of anorymous consizuntications.]

\section{Sub. Wealden Exploration}

IN NATURE, vol, xi. p. 267, the Rev. J. F. Blake calls attention to the announcement that it is proposed by the Sub-Wcalden Exploration Committes to abandon the present bore-hole and to begrin again near tic same spot. He asks why should not another spot be chosen; and suggests that it would be advisable to bore much more to the north-east, because there the Palrozoic rocks would be nearer the surface, and because at the present hole we have already learnt all that is necessary. May I be permitted to reply to these remarks?

In the first ylace, it should not be forgotten that to search for coal measures, or even for the Palzeozoic rocks, is only one object of the exploration. In a purely scientific point of view, it is as important to determine the thickness and character of the Oolitic strata-so far removed from their surface outcrop-as it is to reach the older rocks. If it be true that the boring has been put down where the Oolitic series is well developed, then this object will be the better attained.

But there is even now no proof that the Palrozoic rocks must necessarily be very deep at Netherfield. We are not entitled to infer from the great development of any one member of the Oolitic series that the lower members will also be well developed at that spot. The Oolitic rocks in the Boulonnais come on in force as we recede from the Palæozoic area of Marquise. The Kimmeridge clay is well developed in the Pays de Bray; it is $I, 000$ feet thick near Rouen, and, on its outcrop to the south. west of that city, is underlain by Lower Oolites. One might therefore well have supposed that in the Pays de Bray there 